\title{
UJI AKTIVITAS ANTIBAKTERI TERHADAP BAKTERI PATOGEN DAN IDENTIFIKASI SENYAWA AKTIF EKSTRAK KULIT KAYU RARU (Vatica leucocapra)
}

\section{ANTIBACTERIA ACTIVITY EXPERIMENT ON PATHOGEN BACTERIA AND ACTIVE COMPOUND IDENTIFICATION ON RARU WOOD BARK (Vatica leucocapra)}

\author{
N Verawati ${ }^{1 a}$ dan N Aida ${ }^{2}$ \\ ${ }^{1}$ Jurusan Teknologi Pengolahan Hasil Perkebunan, Politeknik Negeri Ketapang. \\ .2 Jurusan Teknik Sipil, Politeknik Negeri Ketapang. \\ a Korespondensi: Nenengsih Verawati, E-mail: nenengerman_1@yahoo.com \\ (Diterima: 22-06-2017; Ditelaah: 23-06-2017; Disetujui: 15-10-2017)
}

\begin{abstract}
Raru is a forest tree which has height about $70-85 \mathrm{~cm}$, has thick bark, which is usually processed to become powder in Kalimantan, called resak wood bark. It's usually used as a preservative on nira nipah. Based on Fuad (2010), raru wood bark has compound such as terpenoid, arilpropanoide, benzofurane, flovonoide, hidroquinon and oligostilbenoide. The aims of this experiment are to identified clear zone from several consentration (90\%, 95\% and 99\%) and active compound on raru wood bark extract. The treatments are soxhlet extraction with ethanol and methanol solvent (p.a.). Each extraction is done three times so there will be 18 experimental units. Rendement was analyzed by the antibacteria activity and the active compound identification with GC-MS. Result of this experiment is analyzed descriptively with microsoft excel programe and the data is showed in tabels and graphs or histograms. The result of the experiment are the highest rendement taken from methanol extraction treatment, is 35,65\%. The best treatment is taken from antibacterial activity examination of methanol solvent treatment ( $99 \%$ consentration). Raru wood bark extract more effectively to inhibit gram positive bacteria (S. Aureus) than gram negative bacteria (E. Coli). Chromatogram GC-MS identified hexadecanoic acid as an active compound in raru wood bark, which belongs to carboxylic acid group.
\end{abstract}

Keywords: antibacteria activity, GC-MS, raru wood bark.

\begin{abstract}
ABSTRAK
Tanaman raru adalah jenis tanaman hutan yang memiliki tinggi 70-85 cm, memiliki kulit yang tebal kemudian diolah menjadi serbuk oleh masyarakat wilayah Kalimantan biasa dinamakan kulit kayu resak yang biasanya dimanfaatkan sebagai bahan pengawet nira nipah . berdasarkan dari penelitian, kayu raru memiliki kandungan senyawa terpenoid, arilpropanoid, benzofuran, flavonoid, hidrokuinon dan oligostilbenoid (Fuad, 2010). Penelitian ini bertujuan untuk mengetahui zona hambat dari beberapa konsentrasi ekstrak kulit kayu raru dan mengetahui senyawa apa saja yang terkandung pada ekstrak kulit kayu raru. Metode penelitian yang digunakan adalah eksoperimental deskriptif yaitu menggunakan ekstraksi soxhlet yaitu pelarut etanol dan methanol (p.a). Masing-masing ekstraksi tersebut dilakukan 3 kali ulangan sehingga diperoleh 18 satuan percobaan. Data hasil pengamatan dianalisa dengan dua macam analisa yaitu analisa deskriptif menggunakan mikrosoft Excel. Data hasil pengamatan ditampilkan dalam bentuk tabel, dan untuk mudah interpretasi data maka dibuat grafik atau histogram. Analisa ini digunakan analisa rendemen, untuk uji aktivitas antibakteri, dan identifikasi senyawa aktif kulit kayu raru metode GC-MS. Data hasil penelitian menunjukkan rendemen tertinggi pada ekstrak kulit kayu raru yang menggunakan pelarut etanol dan hasil uji zona hambat diperoleh pada ekstrak kulit raru yang menggunakan pelarut etanol dengan bakteri uji
\end{abstract}


S.aureus. Hasil penelitian diperoleh rendemen paling tinggi diperoleh pada penggunan pelarut metanol yaitu 35,65\%. Perlakuan terbaik diperoleh pada aktivitas antibakteri dengan pelarut metanol 99\%. Bakteri gram positif yaitu S.aureus lebih sensitif terhadap aktivitas antibakteri.

Kata kunci: aktivitas antibakteri, GC-MS, kulit kayu raru.

Verawati N dan N Aida. 2017. Uji Aktivitas Antibakteri terhadap Bakteri Patogen dan Identifikasi Senyawa Aktif Ekstrak Kulit Kayu Raru (Vatica Leucocapra). Jurnal Pertanian 8(2): 82-90.

\section{PENDAHULUAN}

Tanaman raru adalah jenis tanaman hutan yang memiliki tinggi 70-85 m, memiliki kulit yang tebal kemudian diolah menjadi serbuk oleh masyarakat wilayah Kalimantan biasa dinamakan kulit kayu resak yang biasanya dimanfaatkan sebagai bahan pengawet nira nipah. berdasarkan dari penelitian terdahulu, kayu raru memiliki kandungan senyawa terpenoid, arilpropanoid, benzofuran, flavonoid, hidrokuinon dan oligostilbenoid (Fuad, 2010). Penelitian tentang senyawa antibakteri yang terdapat pada kulit kayu raru masih belum ada sehingga perlu dilakukan penelitian ekstrak kulit kayu raru pada beberapa bakteri patogen serta identifikasi senyawa yang terkandung dalam kulit kayu raru yang aktif sebagai antibakteri.

Berdasarkan beberapa uraian diatas, maka diharapkan serbuk kayu raru tidak hanya untuk pengawet nira, namun bisa diaplikiasikan sebagai biopreservasi pada beberapa bahan pangan lainnya, terutama dapat menghambat aktivitas bakteri patogen yaitu Staphylococcus aureus, dan Escerichia coli serta dapat diketahui identifikasi senyawa aktif sebagai antibakrteri pada ekstrak kulit kayu raru.

Staphylococcus aureus dan Escerichia coli adalah bakteri Gram positif, yang sering ditemukan pada semua jenis makanan karena dapat menghasilkan toksin sehingga dapat menyebabkan keracunan pada makanan. Sedangkan Eschericia coli merupakan bakteri gram negatif menyebabkan diare pada manusia (Stewart, 2003 dalam Chotiah, S., 2010).

Aktivitas senyawa antibakteri serbuk kayu raru terhadap bakteri patogen pada penelitian ini diamati berdasarkan pada parameter analisa rendemen, zona hambat dan identifikasi senyawa aktif diperoleh berdasarkan hasil dari kromatografi gas spektrofotometri massa.

\section{MATERI DAN METODE}

\section{Materi}

Bahan-bahan yang digunakan antara lain: Kulit kayu raru diperoleh didaerah sungai rengas Kec. Siantan Kab. pontianak, kapas, Media NB (Nutrien Broth) (Pronadisa), Aquades (panadia), bacteriological agar (Pronadisa), Kertas pembungkus petri, karet, spiritus, peptone water (pronadisa), $\mathrm{NaOH}$, dan plastik. Bakteri indikator patogen (Escherichia coli, dan Staphylococcus aereus) yang diperoleh dari Laboratorium mikrobiologi Fakultas Kedokteran Universitas Brawijaya Malang), methanol, etanol kualitas p.a (99\%) (panadia) dan kertas saring whatman (panadia).

\section{Metode}

\section{Tahap dan Metode Penelitian}

\section{Pembuatan bubuk kulit kayu raru}

1. Kulit kayu dicuci dengan air mengalir

2. Kemudian dikeringkan dengan pengering cabinet drying selama \pm 6 jam

3. Pengirisan dengan menggunakan pisau

4. Penggilingan dengan menggunakan blender kering

5. Bubuk kulit kayu raru diayak menggunakan shieve shaker ukuran $\quad 40$ mesh dengan amplindo 60 selama $\quad 10$ menit

6. Bubuk kayu raru yang lolos ayakan dikumpulkan untuk analisa selanjutnya. 


\section{Ekstraksi bubuk kulit kayu raru (Ekstraksi Soxhlet)}

1. Masukkan bubuk kayu raru sebanyak 30 gram masukkan dalam kertas saring.

2. Masukkan kertas saring berisi bubuk kulit kayu raru dalam tabung soxhlet, kemudian rangkai set alat ekstraksi.

3. Isi labu dengan $300 \mathrm{ml}$ pelarut (metanol dan etanol) kualitas p.a

4. Hidupkan kran air, perhatikan sampai air mengalir rata, kemudian hidupkan hot plate atur suhu sesuai titik didih pelarut.

5. Biarkan pelarut mendidih sehingga uap pelarut masuk dalam alat tabung pendingin sehingga terbentuk embun.

6. Biarkan embun menetes dalam kertas saring sehingga akan membasahi bubuk dan akan melarutkan senyawa pada bubuk kulit kayu raru.

7. Pelarut yang tertanpung dalam bak perendam jika penuh maka akan turun mengalir dan masuk kembali dalam labu.

8. Proses tersebut akan berlangsung terusmenerus selama kurang lebih 8 jam.

9. Hasil ekstraksi yang terdapat pada labu kemudian dilakukan penguapan pelarut dengan rotary vacuum evaporator suhu $50^{\circ} \mathrm{C}$, kecepan $60 \mathrm{rpm}$, tekanan $200 \mathrm{mbar}$ selama 45 menit.

10. Ekstrak pekat bubuk kulit kayu raru yang diperoleh kemudian dianalisis rendemen, aktivitas antibakteri dan analisa GC-MS

\section{Pengujian aktivitas antibakteri ekstrak kulit kayu raru}

Uji aktivitas anibakteri metode difusi agar (Pupinmadita,2010)

1. Nutrient agar (NA) yang telah disterilisasi didinginkan hingga suhu $50^{\circ} \mathrm{C}$, kemudian kultur masing-masing bakteri yang berumur 10 jam dimasukkan ke dalam NA $60 \mu \mathrm{l}$ untuk setiap $20 \mathrm{ml}$ NA.

2. Pembuatan agar cawan dengan ketebalan 4-5 mm, kemudian dibuat 3 sumur pada agar tersebut dengan diameter $5 \mathrm{~mm}$.

3. Penambahan $150 \mu \mathrm{l}$ ekstrak kulit kayu raru ke dalam masing-masing sumur, kemudian diinkubasi pada suhu $37^{\circ} \mathrm{C}$ selama 24 jam dengan posisi cawan keatas.

4. Pengamatan adanya penghambatan dan diukur diameter penghambatan dengan menggunakan alat ukur micrometer/ penggaris. Tahap ini dilakukan sebanyak 3 kali.

\section{Analisis Data}

Data hasil pengamatan dianalisa menggunakan deskriptif mikrosoft Excel dan ditampilkan dalam bentuk tabel untuk mudah interpretasi data maka dibuat grafik atau histogram untuk parameter uji rendemen dan aktivitas antibakteri.

\section{HASIL DAN PEMBAHASAN}

\section{Hasil}

Pengaruh jenis pelarut terhadap rendemen ekstrak (\% dry basis) dapat dilihat seperti pada Tabel 1.

Tabel 1 Pengaruh jenis pelarut terhadap rendemen ekstrak (\% dry basis)

\begin{tabular}{|c|c|c|}
\hline Pelarut & $\begin{array}{c}\text { Konsentrasi } \\
(\%)\end{array}$ & $\begin{array}{c}\text { Rendemen } \\
(\%)\end{array}$ \\
\hline \multirow{3}{*}{ Etanol } & 90 & 19,88 \\
\hline & 95 & 24,23 \\
\hline & 99 & 27,31 \\
\hline \multirow{3}{*}{ Metanol } & 90 & 30,59 \\
\hline & 99 & 32,64 \\
\hline & 95 & 35,65 \\
\hline
\end{tabular}

Adapun aktivitas antibakteri ekstrak kulit kayu raru dengan menggunakan pelarut etanol dapat dilihat pada Tabel 2 .

Tabel 2 Aktivitas antibakteri ekstrak kulit kayu raru dengan menggunakan pelarut etanol

\begin{tabular}{lcccccc}
\hline \multirow{2}{*}{$\begin{array}{c}\text { Konsentrasi } \\
\text { Etanol }\end{array}$} & \multicolumn{3}{c}{ Eona Hambatan (mm) } \\
\cline { 2 - 7 } & 1 & 2 & 3 & 1 & 2 & 3 \\
\hline $90 \%$ & 1,1 & 1,3 & 1,2 & 4,2 & 3,1 & 4,1 \\
$95 \%$ & 2,4 & 2,4 & 2,4 & 4,3 & 4,4 & 4,4 \\
$99 \%$ & 2,7 & 2,4 & 2,6 & 4,7 & 4,6 & 4,5 \\
\hline
\end{tabular}


Tabel 3 Aktivitas antibakteri ekstrak kulit kayu raru dengan menggunakan pelarut methanol

\begin{tabular}{ccccccc}
\hline \multirow{2}{*}{$\begin{array}{c}\text { Konsentrasi } \\
\text { Metanol }\end{array}$} & \multicolumn{3}{c}{ Eona hambatan (mm) } \\
\cline { 2 - 7 } & 1 & 2 & 3 & 1 & 2 & 3 \\
\hline $90 \%$ & 1,55 & 2 & 2,1 & 4,3 & 4,5 & 5,05 \\
$95 \%$ & 2,55 & 2,55 & 2,75 & 5,07 & 5,15 & 5,07 \\
$99 \%$ & 2,87 & 2,87 & 2,75 & 5,5 & 5,17 & 5,17 \\
\hline
\end{tabular}

\section{Pembahasan}

\section{Rendemen Ekstrak}

Rendemen ektrak dihitung berdasarkan dry basis yaitu membagi berat (gram) ekstrak yang diperoleh dengan berat (gram) bahan kering yang diekstrak dikalikan $100 \%$.

Rendemen ektrak kulit kayu raru dengan menggunakan metode soxhlet dapat di lihat pada Tabel 3.1 menunjukkan penggunaan jenis pelarut metanol dan etanol memberikan pengaruh terhadap rendemen yang dihasilkan. Pelarut metanol dan etanol akan melarutkan senyawa yang berbeda polaritasnya. Senyawa yang terekstrak dalam pelarut lalu berdifusi keluar akibat gaya yang ditimbulkan karena adanya perbedaan konsentrasi di dalam dan di luar sel. Prinsip like-dissolve like menerangkan, senyawa polar akan terlarut dalam pelarut polar atau sebaliknya (Kristanti et al., 2008).

Pelarut metanol menghasilkan rendemen lebih tinggi dibandingkan pelarut etanol, hal ini karena metanol mempunyai kemampuan mengekstrak komponen dalam sel kulit kayu raru lebih baik daripada pelarut etanol. Metanol adalah pelarut polar sehingga sangat sesuai untuk mengekstrak kandungan senyawa dalam kulit kayu raru. Kandungan kimia yang terdapat pada kulit kayu raru adalah senyawa flavonoid, tanin, saponin, polifenol, alkoloid, dan hidrokuinon (Gunawan 2011).

\section{Aktivitas Antibakteri Ekstrak Kulit Kayu Raru}

Aktivitas antibakteri pada penelitian ekstrak kulit kayu raru ini dapat diketahui melalui metode sumuran (Wolf, C.E. dan R. Gibbons, 1996). Daya hambat antibakteri ditunjukkan dengan zona bening yang terbentuk di sekitar sumuran berisi ekstrak sampel. Pada media agar tanpa ada penambahan antibakteri, koloni bakteri uji akan tumbuh merata pada media agar, namun pada media agar yang terdapat ekstrak pada beberapa titik bakteri tidak dapat tumbuh karena adanya ekstrak sampel sehingga bakteri uji yang digunakan tidak dapat tumbuh. Pada beberapa titik yang tidak dapat ditumbuhi media disebut dengan zona bening, bila zona bening terbentuk besar, maka kemampuan penghambatan suatu antibakteri terhadap bakteri uji akan semakin tinggi. Bakteri uji yang digunakan pada penelitian ini adalah S.aureus dan E.coli.

Bakteri uji yang digunakan pada penelitian ini jumlahnya sama yaitu 2,1 x $10^{4} \log \mathrm{CFU} / \mathrm{ml}$. Bakteri yang digunakan pada pengujian ini berada pada medium fase log. Fase log merupakan fase pertumbuhan bakteri dengan sangat cepat karena aktivitas metabolisme bakteri berlangsung paling maksimal dan reproduksi sel pada fase ini melebihi jumlah sel yang mati (Anonymous, 2010).

\section{Aktivitas antibakteri ekstrak kulit kayu raru dengan menggunakan pelarut etanol}

Etanol merupakan polar yang banyak digunakan untuk mengesktrak komponen fitokimia dari tumbuhan. Air dan etanol adalah jenis pelarut yang banyak digunakan karena toksisitasnya yang rendah dan proses ekstraksi dapat berlangsung secara maksimal. Pada penelitian ini digunakan pelarut etanol dengan konsentrasi 90, 95 dan 99\%, agar dapat diketahui konsetrasi etanol yang paling efektif untuk digunakan dalam proses ekstraksi senyawa antibakteri ekstrak kulit kayu raru yang dapat ditunjukkan melalui pembentukkan zona bening pada uji sumuran seperti pada Gambar 1.

Etanol sebagai pelarut juga memiliki kemampuan sebagai desinfektan oleh karena itu dilakukan pengujian terhadap daya hambat yang menggunakan bakteri uji E.coli dan S.aureus dapat dilihat pada Gambar 1.

Gambar 1 menunjukkan bahwa semakin tinggi konsentrasi etanol yang digunakan untuk pelarut dalam ekstraksi senyawa antibakteri pada ekstraksi kulit kayu raru, maka semakin besar zona hambat yang 
terbentuk. Hal tersebut karena adanya senyawanya antibakteri yang terekstrak, karakteristik etanol yang bersifat disenfektan juga turut mempengaruhi besarnya zona penghambatan ekstrak kulit kayu raru terhadap pertumbuhan bakteri uji. Sehingga semakin tinggi konsentrasi etanol yang digunakan sebagai pelarut pada proses ekstraksi, maka semakin tinggi juga daya hambat yang dihasilkan.

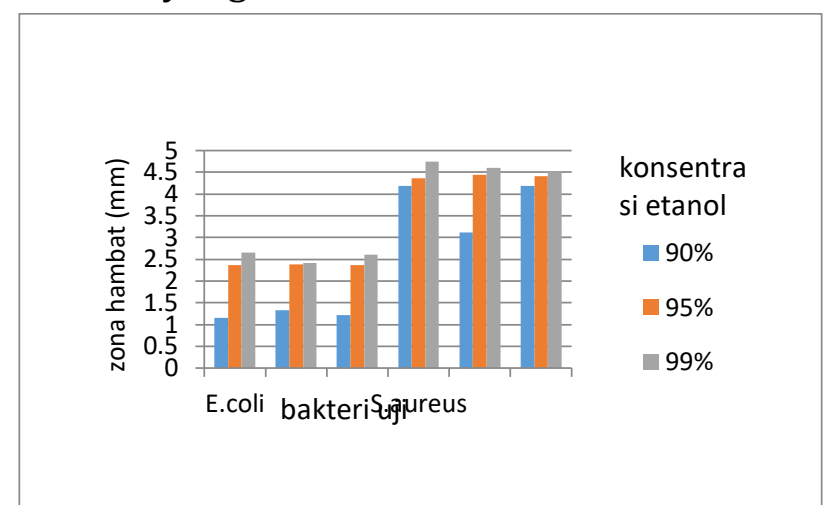

Gambar 1 Pengaruh konsentrasi etanol pada ekstraksi kulit kayu raru terhadap zona hambat bakteri uji

Pasaribu, G (2011), yang menyatakan bahwa etanol memiliki 2 gugus yang berbeda kepolarannya yaitu gugus hidroksil yang bersifat polar dan gugus alkil yang bersifat non polar. Dengan adanya 2 gugus ini diharapkan senyawa-senyawa dengan tingkat kepolaran yang berbeda akan terekstrak ke dalam pelarut etanol. Tingginya aktivitas antibakteri dari ekstrak dengan pelarut etanol mengidikasikan bahwa semakin banyak senyawa antibakteri yang ikut terlarut selama ekstraksi.

Dalam ekstraksi menggunakan pelarut, faktor-faktor yang mempengaruhi kecepatan reaksi yaitu difusi antara pelarut dengan zat terlarut. Faktor difusi ini ditentukan oleh viskositas pelarut, ukuran dan bentuk partikel zat terlarut. Kelarutan zat terlarut di dalam zat pelarut tergantung pada kepolaran, interaksi dipol-dipol, ikatan hidrogen dan suhu (Neckers, D. C, 1977).

Aktivitas antibakteri dari penggunaan bakteri uji Staphylococcus aureus dan Escerichia coli menunjukkan hasil zona bening lebih besar pada bakteri uji Staphylococcus aureus hal ini karena Staphylococcus aureus merupakan kelompok bakteri gram positif sedangkan Escerichia coli merupakan kelompok bakteri gram negatif yang memiliki perbedaan struktur penyusun dinding sel.

Staphylococcus aureus merupakan kelompok bakteri gram positif yang memiliki satu lapis membran peptidoglikan yang tebal dengan sedikit lipida (1-4\%), membran peptidoglikan ini mudah terlarut oleh etanol (Brock, et al., 1994). Sedangkan Escerichia coli merupakan kelompok bakteri gram negatif yang memiliki dinding sel yang banyak mengandung banyak lipida (11-22\%). Komposisi garam negatif yang banyak mengandung lipida inilah yang menyebabkan didnding sel bakteri garam negatif lebih sensitif terhadap zat asing (Tortora, et al 2001)

Untuk dapat mempengaruhi atau membunuh bakteri, bahan uji harus masuk ke dalam sel bakteri melalui dinding sel bakteri. Dengan perbedaan komposisi penyusun didinding sel gram positif dan gram negatif, maka kemampuan ekstrak kulit raru terhadap bakteri indikator juga akan berbeda. Doyle, M. P. dan D. O. Cliver (1990) menerangkan bahwa bakteri gram negatif memiliki outer membrane sebagai pelindung terhadap zatzat yang bersifat racun, sehingga tidak mudah dipengaruhi oleh antibakteri yang mempunyai target menghambat sintesis peptidoglikan sebagai komponen dinding sel. Ketika bahan uji mampu menembus dinding sel bakteri, maka dinding sel bakteri akan melemah, sehingga sel akan mengalami lisis.

Kandungan kimia yang terdapat pada kulit kayu raru juga memberikan pengaruh terhadap aktivitas antibakteri yaitu senyawa terpenoid, arilpropanoid, benzofuran, flavonoid, hidrokuinon dan oligostilbenoid (Fuad, 2010).

\section{Aktivitas antibakteri ekstrak kulit kayu raru dengan menggunakan pelarut metanol}

Metanol merupakan pelarut yang memiliki polaritas yang tinggi, struktur alkohol yang paling sederhana dengan adanya gugus hidroksil dan hanya memiliki satu atom $\mathrm{C}$ sebagai penyusun rantai karbonnya menyebabkan metanol memiliki polaritas 
tinggi dibanding dengan jenis alkohol jenis lainnya.

Karakteristik metanol yang sangat polar, metanol sangat banyak digunakan sebagai pelarut dalam proses ekstraksi untuk melarutkan komponen polar dari suatu bahan. Penggunaan metanol dalam penelitian ini bertujuan untuk melarutkan senyawa antibakteri yang bersifat polar sehingga dapat dibandingkan dengan pelarut yang polaritasnya lebih rendah (etanol).

Pada penelitian ini tidak hanya menggunakan etanol, namun digunakan juga metanol dengan beberapa konsentrasi yang bertujuan untuk mengekstrak senyawa antibakteri dari kulit kayu raru. Konsentrasi metanol yang digunakan adalah 90\%, $95 \%$ dan 99 \%. Hasil dari ekstraksi berupa ekstrak kulit kayu raru selanjutkan dilakukan pengujian zona hambat dengan menggunakan bakteri uji e.coli dan s. aureus yang dapat dilihat pada Tabel 4.

Tabel 4 Zona hambat ekstrak kulit kayu raru yang menggunakan pelarut metanol

\begin{tabular}{cccc}
\hline \multirow{2}{*}{$\begin{array}{c}\text { Sampel } \\
\text { uji }\end{array}$} & $\begin{array}{c}\text { Konsentrasi } \\
\text { pelarut }\end{array}$ & \multicolumn{2}{c}{$\begin{array}{c}\text { Zona hambat } \\
(\mathrm{mm})\end{array}$} \\
\cline { 3 - 4 } Ekstrak & \multicolumn{2}{c}{ Bakteri uji } \\
\cline { 2 - 4 } kulit & & E.coli & S.aureus \\
kayu & $90 \%$ & 1,88 & 4,61 \\
raru & $95 \%$ & 2,61 & 5,09 \\
& $99 \%$ & 2,83 & 5,28 \\
\hline
\end{tabular}

Berdasarkan Tabel 4, diperoleh zona hambat tertinggi diperoleh pada konsentrasi metanol 99\% dengan bakteri uji S.aureus. Semakin tinggi konsentrasi metanol yang digunakan untuk mengekstrak sampel kulit kayu raru maka diperoleh zona hambat semakin tinggi yang dapat dilihat dalam bentuk zona hambat di sekitar sumuran pada media agar. Peningkatan zona hambat dapat di lihat pada Gambar 2.

Konsentrasi metanol semakin tinggi dalam suatu larutan berarti bahwa kadar air di dalam larutan tersebut semakin kecil. Air sebagai pelarut dengan polaritas paling tinggi.
Dengan demikian, semakin tinggi konsentrasi metanol, maka polaritasnya akan semakin menurun seiring dengan semakin kecilnya kadar air didalam larutan. Maka dapat diketahui bahwa semakin tinggi konsentrasi metanol maka akan semakin efektif dalam mengekstrak senyawa antibakteri pada kulit kayu raru. Hal tersebut sesuai penelitian Dailami (2010), dimana daun seledri yang menggunakan pelarut metanol lebih baik dalam mengekstraksi senyawa antibakteri berupa senyawa flavonoid.

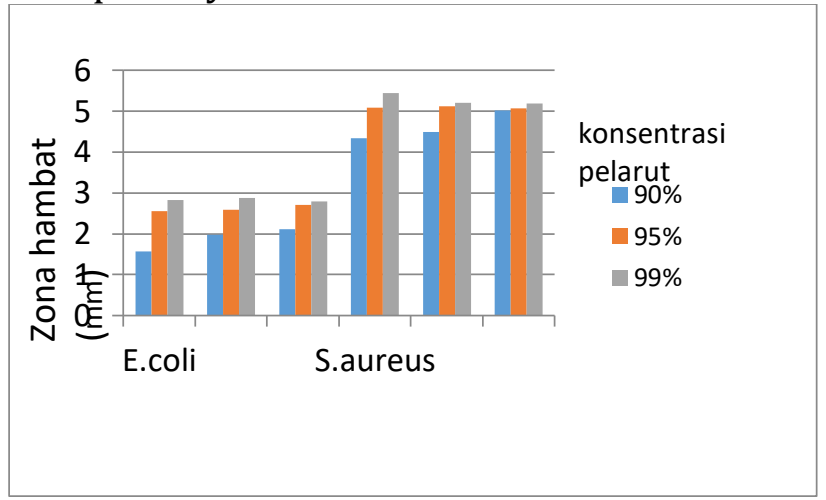

Gambar 2 Pengaruh konsentrasi metanol pada ekstraksi kulit kayu raru

Flavonoid dapat berefek antibakteri melalui kemampuan untuk membentuk kompleks dengan protein ekstraseluler dan protein yang dapat larut serta dengan dinding sel bakteri (Robinson, 1995 dalam Ardananurdin dkk, 2004). Triterpenoid dapat menghambat pertumbuhan atau mematikan bakteri dengan mengganggu proses terbentuknya membran dan atau dinding sel, membran atau dinding sel tidak terbentuk atau terbentuk tidak sempurna (Ajizah, 2004).

\section{Analisa Senyawa Aktif Ekstrak Kulit Kayu Raru dengan Kromatografi Gas Spektrofotometri Massa}

Hasil ekstrak kulit kayu raru sangat aktif sebagai antibakteri berdasarkan pada hasil yang diperoleh pada uji aktivitas antibakteri metode sumuran, berdasarkan pada hasil tersebut diatas maka dilanjutkan dengan uji Kromatografi Gas Spektrofotometri Massa. 


\section{Ekstrak Etanol Kulit Kayu Raru}

Kromatogram KG-MS dari senyawa hasil identifikasi ekstrak etanol kulit kayu raru dapat di lihat pada Gambar 3.

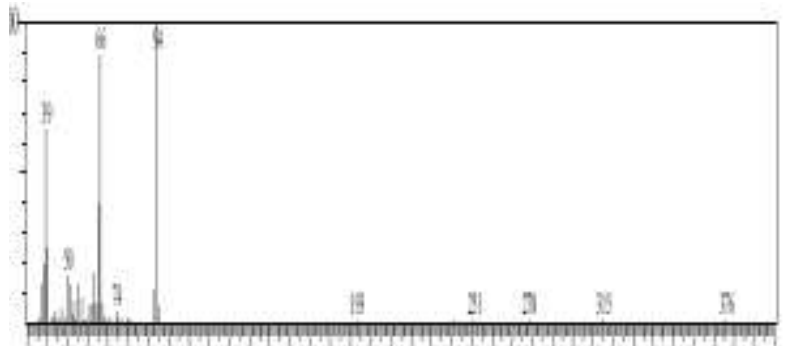

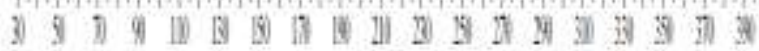

Gambar 3 Kromatogram KG-MS kulit kayu raru dengan pelarut etanol

Keterangan: Angka yang tertera diatas puncak adalah nomor puncak seperti yang ditampilkan pada tabel 5

Tabel 5 Kromatogram KG-MS kulit kayu raru dengan pelarut etanol

\begin{tabular}{cll}
\hline $\begin{array}{c}\text { No. } \\
\text { Puncak }\end{array}$ & \multicolumn{1}{c}{ Nama } & $\begin{array}{l}\text { Golongan } \\
\text { senyawa }\end{array}$ \\
\hline 39 & $\begin{array}{l}\text { hydroxycinnamic } \\
\text { acid }\end{array}$ & $\begin{array}{l}\text { Fenol } \\
\text { asam }\end{array}$ \\
50 & hexadecanoic acid & karboksilat \\
94 & pamitic acid & $\begin{array}{l}\text { Asam } \\
\text { palmitat }\end{array}$ \\
\hline
\end{tabular}

Golongan senyawa paling dominan terdapat dalam ekstrak etanol adalah senyawa asam karboksilat. Asam karboksilat merupakan senyawa utama dalam ekstrak etanol kulit kayu raru. Asam karboksilat mempunyai gusus karbonil yang dapat berinteraksi dengan komponen protein dari enzim. Interaksi ini menyebabkan terjadinya perubahan pada sisi aktif enzim, yang lebih lanjut dapat mengganggu substrat dengan enzim.

Black (2005) menyatakan mekanisme penghambatan enzim seperti ini disebut sebagai penghambatan yang nonkompetitif yaitu senyawa hexadecanoic acid yang berperan sebagai antibakteri. Hal ini sesuai dengan pernyataan Pavithra, et al (2009), yang menyatakan bahwa hexadecanoic acid yang terkandung dalam Pamburus misionis mempunyai efek antibakteri pada beberapa strain bakteri.

\section{Ekstrak Metanol Kulit kayu Raru}

Kromatogram KG-MS dan senyawa-senyawa hasil identifikasi KG-MS ekstrak kulit kayu raru dapat dilihat pada Gambar 4 dan Tabel 6 .

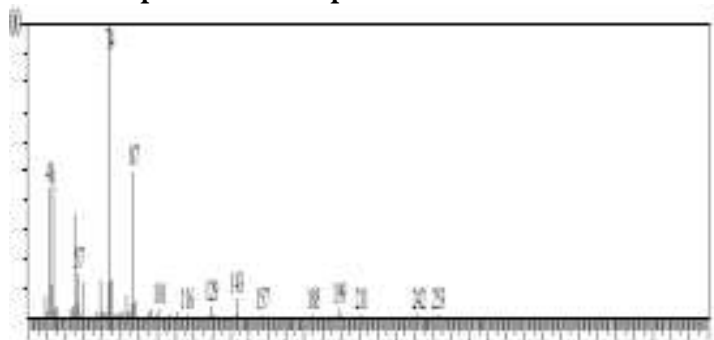

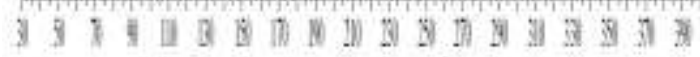

Gambar 4 Kromatogram KG-MS kulit kayu raru dengan pelarut metanol

Tabel 6 Hasil identifikasi senyawa aktif dalam kulit kayu raru dengan pelarut metanol

\begin{tabular}{cll}
\hline $\begin{array}{c}\text { No. } \\
\text { Puncak }\end{array}$ & \multicolumn{1}{c}{ Nama } & \multicolumn{1}{c}{$\begin{array}{l}\text { Golongan } \\
\text { senyawa }\end{array}$} \\
\hline 41 & metil ester & Ester \\
74 & $\begin{array}{l}\text { hexadecanoic } \\
\text { acid }\end{array}$ & $\begin{array}{l}\text { Asam } \\
\text { karboksilat } \\
87\end{array}$ \\
$\begin{array}{l}\text { Octadekanoic } \\
\text { acid }\end{array}$ & $\begin{array}{l}\text { asam } \\
\text { karboksilat }\end{array}$ \\
\hline
\end{tabular}

Berdasarkan pada Gambar 4 menunjukkan senyawa yang teridentifikasi yang mempunyai peak paling tinggi yaitu hexadecanoic acid dan Octadekanoic acid yang termasuk dalam golongan senyawa asam karboksilat. Senyawa hexadecanoic acid dan Octadekanoic acid merupakan senyawa antibakteri yang memiliki sensitifitas yang sangat bagus. Mc. Gaw, et al, (2002), menyatakan senyawa antibakteri yang diisolasi dari schotia brachypetala mengandung Octadekanoic acid yang menunjukkan antibakteri yang baik terhadap bakteri gram positif maupun negatif. Casas campilo C, et al, (1961), menyatakan asam karboksilat jenis fatty acid tertentu dapat menghambat aktivitas enzim-enzim yang berperanan penting dalam perkembangan bakteri.

Selain itu, Black (2005) juga menyatakan bahwa bakteri maupun khamir dapat mensintesa eksoenzim yang dilepas melalui 
membran sel yang digunakan untuk menghidrolisis substrat seperti karbohidrat, protein dan lemak.

\section{KESIMPULAN DAN IMPLIKASI}

\section{Kesimpulan}

Berdasarkan pada beberapa parameter hasil penelitian maka diperoleh kesimpulan sebagai berikut.

1. Rendemen paling tinggi diperoleh pada pelarut metanol yaitu $35,65 \%$.

2. Perlakuan terbaik aktivitas antibakteri ditunjukkan oleh ekstrak kulit kayu raru dengan pelarut metanol $99 \%$.

3. Bakteri gram positif lebih sensitif terhadap aktivitas antibakteri ekstrak kulit kayu raru dibandingkan bakteri gram negatif.

4. Hasil identifikasi menggunakan metode Kromatogram GC-MS diperoleh senyawa hexadecanoic acid yang termasuk dalam golongan senyawa asam karboksilat.

\section{Implikasi}

Kesulitan dalam penelitian ini adalah menghaluskan kulit raru, kemudian laboratorium yang belum lengkap khususnya di Politeknik Negeri Ketapang sehingga untuk beberapa analisa harus di kirim ke Laboratorium Kimia di UGM. Diharapkan untuk penelitian selanjutnya tentang aplikasi kayu raru sebagai bahan pengawet makanan dan minuman.

\section{DAFTAR PUSTAKA}

Anonymous. 2010. Fase Pertumbuhan Bakteri.

http://www.alexcosie.blogspot.com/2010 /11/fase-pertumbuhan-bakteri. Tanggal Akses 22 Februari 2011.

Ajizah. 2004. Sensitivitas Salmonella Typhimurium terhadap Ekstrak Daun Psidium Guajava L. Jurnal Bioscientiae. 1(1). Hal 31-38.

Ardananurdin dkk. 2004. Uji Efektivitas Dekok Bunga Belimbing Wuluh (Averrhoa
Bilimbi) Sebagai antimikroba terhadap bakteri Salmonella Typhi secara in vitro. Jurnal Kedoktera Brawijaya. 20(1). Hal 3537.

Black, J.G. 2005. Microbiology Principles and Exporations. Jhon Wiley and Sons, Inc. Airlington.

Brock, T.D., M.T . Madigan., J.M. Martinko and J. Parker. 1994. Biology of Microorganisms. Prentice- Hal 1. International, Inc. New Jersey.

Casas campillo C, et al. (1961). Steroids clix, antimicrobial properties of 21, 21dimethoxy progesterone and other progesteron analogues. J. Bacteriol. 81(3). Hal 366-375.

Chotiah, S. 2010. Beberapa Bakteri Patogen yang Mungkin dapat ditemukan pada Susu Sapi dan Pencegahannya. Semiloka Nasional Prospek Industri Sapi Perah Menuju Perdagangan Bebas 2020. Balai Besar Penelitian. Bogor.

Dailami, M. 2010. Skrining Fitokimia Herbal Seledri, Daun Jambu Biji, dan Buah Cabe Merah. UNIPA.

Doyle, M. P. dan D. O. Cliver. 1990. Escherichia coli dalam D.O. Cliver (eds) : Food Borne Diseases. Academic Press, Inc, San Diego. Hal 210-214.

Fuad. 2010. Pengaruh Penambahan Serbuk Kulit Kayu Resak, Perebusan dan Radiasi Sinar Ultraviolet Terhadap Nira Nipah. Program Studi Teknologi Hasil Pertanian. Universitas Brawijaya. Malang.

Gunawan. P. 2011. Manfaat Kulit Tanaman raru. Jurusan pertanian. Universitas Negeri Medan.

Kristanti, N.A., Aminah, N.S., Tanjung, M., Kurniadi, B. 2008. Buku Ajar Fitokimia. F.MIPA. Universitas Airlangga. Surabaya.

Kusmiyati, N.W.S., dan Agustini. 2007. Uji Aktivitas Senyawa Antibakteri dari Mikroalga Porphyridium cruetum. Biodiversitas. 8(1). Hal 48-53.

McGaw, L.J,A.K. Jager and J. Van Staden. 2002. Isolation of Antibacterial Fatty Acids from Schotia Branchypetala. Research Centre for plant Growth and Development. University of Natal Pietermaritzbug South Africa.

Neckers, D. C. 1977. Ketenes. J. Am. Chem. Soc. 99(12). Hal 4111-4118. 
Pasaribu, G. 2011. Aktvitas inhibisi alfa glukosidase pada beberapa jenis kayu raru. Jurnal Penelitian Hasil Hutan. 29(1). Hal 10-19.

Pavitra, P.S, N. Sreevidya and R.S. Verma. 2009. Antibacterial Activity and Chemical Composition of Essensial Oil of Pamburus
Missionin: Journal of Ethnopharmacology. 24 (1). Hal .151-153.

Tortora, et al. 2001. Microbiology in Introduction. International Edition. New York. Banjamin Cummings, Inc.

Wolf, C.E. dan R. Gibbons. 1996. Improved method for qualification of bacteriocins nisin. J. Appl. Bacteriol. 80: 463. 